\title{
Introduction of foreign genes into the tissue of live fish by direct injection and particle bombardment
}

\author{
Marta Gómez-Chiarri ${ }^{1, *}$, Sandra K. Livingston ${ }^{2}$, Carlos Muro-Cacho ${ }^{2}$, \\ Sunny Sanders ${ }^{1}$, Robert Paul Levine ${ }^{1}$ \\ ${ }^{1}$ Hopkins Marine Station, Stanford University, Pacific Grove, California 93950, USA \\ ${ }^{2}$ Department of Pathology, H Lee Moffitt Hospital, University of South Florida, Tampa, Florida 33612, USA
}

\begin{abstract}
We compared 2 methods of direct gene delivery into live rainbow trout Oncorhynchus mykiss tissue, with the final goal of developing DNA-based vaccines for bacterial diseases in salmonids. The introduction of plasmid constructs containing the luciferase and $\beta$-galactosidase reporter genes was achieved either by direct injection or by particle bombardment with DNA-coated gold microparticles. Luciferase expression was observed in homogenates of trout flank muscle and skin $2 \mathrm{~d}$ after injection of 10 to $100 \mu \mathrm{g}$ of DNA per fish or bombardment of $1 \mu \mathrm{m}$ gold particles coated with 5 to $25 \mu \mathrm{g}$ DNA per fish at helium pressures ranging from 2750 to $12400 \mathrm{kPa}$. Expression levels increased over $10 \mathrm{~d}$ and persisted for at least $60 \mathrm{~d}$ after injection. For particle bombardment, the most reproducible levels of luciferase expression were obtained with the eye as a target $(83 \%$ of fish positive versus $59 \%$ of fish positive when the flank was the target). The levels of luciferase expression observed after particle bombardment were significantly lower $(t$-test, $p<0.02)$ than the levels measured after direct injection. Immunohistochemical analysis indicated $\beta$-galactosidase gene expression in muscle cells at the site of injection and in the dermis, epidermis and muscle after bombardment. These 2 methods may prove valuable for the development of a new generation of DNA-based vaccines for fish.
\end{abstract}

KEY WORDS: DNA-based immunization - Gene transfer - Particle bombardment - Injection - Rainbow trout - Reporter genes - Bacterial kidney disease - Furunculosis

\section{INTRODUCTION}

In recent years, researchers studying fish diseases have increasingly used recombinant DNA technologies for the development of new vaccines for use in aquaculture (Leong 1993, Munn 1994, Press \& Lillehaug 1995). Among the applications of gene transfer, nucleic acid immunization is a promising new approach to vaccination (Tang et al. 1992). Antigen-specific antibody production and protective immunity can be induced by delivering plasmid DNA, containing genes coding for antigenic proteins, into the tissues of live animals (Tang et al. 1992, Cox et al. 1993, Fynan et al. 1993, Robinson et al. 1993, Ulmer et al. 1993, Wang et al. 1993, Raz et al. 1994, Sedegah et al. 1994, Barry et al. 1995, Manickan et al. 1995). The antigen gene is

•E-mail: gomezchi@leland.stanford.edu expressed by the animal cells and appears to stimulate persistent humoral and cellular responses without integration of plasmid into chromosomal DNA (Wolff et al. 1992, Raz et al. 1994). Direct DNA administration obviates the lengthy and costly requirement for purified antigens. Moreover, the resultant prolonged antigen production in vivo approximates what the immune system sees following immunization with a live, attenuated virus or live recombinant vaccine without the risk of infection or the necessity of adjuvants and boosters (reviewed by Davis \& Whalen 1995).

Particle bombardment and direct injection have been used to physically introduce genes into the cells and tissues of animals in vivo (Benvenisty \& Reshef 1986, Wolff et al. 1990, Hansen et al. 1991, Williams et al. 1991, Eisenbraun et al. 1993, Sanford 1993). The direct delivery of gene constructs that encode for proteins from the influenza virus, the herpes simplex virus, and the malaria parasite has been shown to con- 
fer protection against these diseases in several species (Cox et al. 1993, Fynan et al. 1993, Ulmer et al. 1993, Raz et al. 1994, Sedegah et al. 1994, Manickan et al. 1995).

Despite many attempts, development of an effective vaccine for some bacterial diseases that affect salmonids, such as bacterial kidney disease (BKD), has not been achieved (Newman 1993). In order to develop DNA-based vaccines for 2 bacterial diseases of very different characteristics, BKD and furunculosis, we tested injection and particle bombardment as methods to introduce genes into the tissue of live fish. We used eukaryotic expression vectors carrying either the luciferase or the $\beta$-galactosidase reporter genes to evaluate the effects of the route of delivery, the DNA concentration, and the target tissue on the efficiency of in vivo transfection in rainbow trout Oncorhynchus mykiss.

\section{MATERIALS AND METHODS}

Plasmid expression vectors. The expression vectors pCMVtkluc and pCMVtklacz contain the cytomegalovirus (CMV) enhancer and the herpes simplex virus thymidine kinase (tk) promoter coupled to the luciferase (luc) and $\beta$-galactosidase (lacz) reporter genes, respectively (Winkler et al. 1992). The plasmid pCMVtkluc was used to quantify the production of the reporter protein in tissue lysates while pCMVtklacz was used to determine by immunohistochemistry the type and location of the cells that expressed the protein. The negative control plasmid pluc contains the luciferase gene but lacks a promoter to drive the expression of the gene. Plasmid DNA was purified with QIAGEN tip 500 columns (QIAGEN, Chatsworth, CA, USA). All plasmids were kindly provided by Dr Manfred Schartl.

Fish. Young rainbow trout Oncorhynchus mykiss, 7 to $15 \mathrm{~cm}$ in length, were obtained from the California Fish and Game Nimbus Hatchery and kept in a recirculating freshwater system at $10^{\circ} \mathrm{C}$

Injection of DNA in vivo. Trout ( 3 to 6 in each group) were anesthetized with MS-222 (3-aminobenzoic acid ethyl ester, Sigma, St. Louis, MO, USA) and injected using a tuberculin syringe and a $26 \frac{1}{2} \mathrm{G}$ needle with $100 \mu$ l of plasmid DNA at a range of concentrations $(10$ to $100 \mu \mathrm{g}$ of plasmids pCMVtkluc and/or pCMVtklacz per fish) dissolved in phosphate-buffered saline (PBS). A control group of 5 fish was injected with $100 \mu l$ of PBS or $50 \mu \mathrm{g}$ of the plasmid pluc in $100 \mu \mathrm{l}$ of PBS. The depth of penetration of the needle into the target tissue was 2 to $5 \mathrm{~mm}$. The sites of injection were the peritoneum, the gills or the flank muscle at the midpoint between the anterior margin of the dorsal fin and the lateral line.
In vivo particle bombardment. Particle bombardment was performed using a prototype of a hand-held device from Bio-Rad (Hercules, CA, USA). In this device, high pressure helium is rapidly released across a rupture membrane creating a shockwave that forces a macrocarrier disk with DNA-coated gold particles on the exterior surface into a screen. The screen stops the macrocarrier but allows the DNA-coated particles to continue at high speed into the tissues. The distance traveled by the microprojectiles is $1.5 \mathrm{~cm}$ and the diameter of the bombarded area is approximately $1 \mathrm{~cm}$. DNA-coated particles were prepared by sequentially adding, while vortexing, varying amounts of gold particles from 50 to $100 \mu \mathrm{l}\left(60 \mathrm{mg} \mathrm{ml}^{-1}\right.$ in water, provided by BioRad), varying amounts of each plasmid from 2.5 to $200 \mu l$ (pCMVtkluc and pCMVtklacz, $1 \mathrm{mg}$ $\mathrm{ml}^{-1}$ ), $100 \mu \mathrm{l}$ of $2.5 \mathrm{M} \mathrm{CaCl}_{2}$ and $60 \mu \mathrm{l}$ of $0.1 \mathrm{M}$ spermidine (Sanford 1993). After a 10 min incubation with gentle agitation, particles were centrifuged for $2 \mathrm{~s}$ in a microfuge, washed once with $70 \%$ ethanol, once with $100 \%$ ethanol, and resupended in $56 \mu \mathrm{l}$ of $100 \%$ ethanol. Six $\mu$ l of the particle suspension were placed on the surface of each macrocarrier and allowed to dry. Trout ( 3 to 6 in each group) were anesthetized with MS-222 and bombarded in the target tissue. The effect of helium pressure (2750 to $12400 \mathrm{kPa}$ ), DNA concentration ( 0.3 to $25 \mu \mathrm{g}$ per fish), particle concentration (375 to $750 \mu \mathrm{g}$ per fish), and particle size (1, 1.6 and $2.2 \mu \mathrm{m}$ ) on the expression of the reporter gene were evaluated using as a target the area between the anterior margin of the dorsal fin and the lateral line. Most of the experiments were performed at least twice. A group of 3 fish was bombarded with particles coated with the promotorless construct pluc as a negative control.

Tissue extraction and luciferase assay. Control and experimental trout were sacrificed at selected time points after the introduction of DNA into the tissue, and tissue samples from the site of injection or bombardment were taken for luciferase assays and histology. For the luciferase assay, muscle and skin tissue samples (approximately $0.5 \mathrm{~cm}^{2}$ ) were homogenized in $2 \mathrm{ml}$ of lysis buffer $[0.1 \mathrm{M}$ potassium phosphate $\mathrm{pH} 7.8$, $1 \%$ Triton X-100, $1 \mathrm{mM}$ dithiotreitol, $2 \mathrm{mM}$ (ethylenedinitrilo)tetraacetic acid] using a Politron (Tekmar Tissuemizer, Cincinnati, OH, USA). Luciferase activity was measured in tissue extracts using the modified Enhanced Luciferase Assay Kit (Analytical Luminescence Laboratory, San Diego, CA, USA) with $20 \mu \mathrm{M}$ Coenzyme A, according to the manufacturer's instructions. Light emission was measured with a single photon count program in a standard liquid scintillation counter (Mark V, Tm Analytic, Bensenville, IL, USA). Following subtraction of background, results were expressed as mean $( \pm S E$ ) counts per minute (cpm) of 
luciferase per mg of protein. No luciferase activity was observed in control fish. Protein concentrations in the tissue lysates were measured using a commercially available Coomassie assay kit (Bio-Rad). The Student's $t$-test was used to compare data from the different trials.

Immunohistochemical detection of $\beta$-galactosidase. Transverse cross-sections of muscle and skin tissue from the site of injection or bombardment were fixed overnight in $1.25 \%$ glutaraldehyde in PBS and washed 3 times with PBS. Tissues were embedded in paraffin, cut to a thickness of $3 \mu \mathrm{m}$, and mounted on silanized slides. Endogenous peroxidase activity was quenched by immersing slides in 3\% hydrogen peroxide aqueous solution. Permeabilization was achieved with trypsin (Sigma) digestion $\left(0.1 \%\right.$ in $\left.0.4 \% \mathrm{CaCl}_{2}\right)$ for 30 min at $37^{\circ} \mathrm{C}$. For immunohistochemical detection of $\beta$-galactosidase a Vectastain Elite $\mathrm{ABC}$ kit (Vector Laboratories, Burlingame, CA, USA) was used as follows. A 1:100 dilution of normal horse serum was used for blocking for 20 min at room temperature. After blotting excess serum, the primary monoclonal antibody, a mouse anti- $\beta$ galactosidase (Boehringer-Mannheim, Indianapolis, IN, USA), was applied at a dilution of 1:1000 for 1 h at room temperature. After washing with PBS, the secondary antibody, a biotinylated horse antimouse-IgG (gamma-chain specific), was applied for 30 min at room temperature at a dilution of $1: 200$. The $A B C$ reagent was applied following manufacturer's instructions using 3,3'-diaminobenzidine (DAB, Sigma) as a chromogen. Development of color was observed under the microscope. Sections were counterstained with Meyer's Hematoxylin, dehydrated in xylene, cleaned, mounted in Accumount (Baxter, McGaw Park, IL, USA], and covered with coverslips. Photographs were taken on a Leitz, Dialux 22EB microscope.

\section{RESULTS}

In order to evaluate the efficiency of injection as a method for the delivery of DNA into live fish, we performed injections of the plasmid pCMVtkluc into different tissues of the trout. The intramuscular injection of 10 to $100 \mu \mathrm{g}$ of DNA per fish in the flank resulted in high levels of luciferase expression in muscle and skin lysates as soon as $2 \mathrm{~d}$ after injection (Fig. 1). The introduction of $50 \mu \mathrm{g}$ of DNA per fish induced significantly higher levels of luciferase expression than the other doses ( $t$-test, $p<0.05$ ). A general trend of increasing mean luciferase activity was observed in fish sacrificed at 10, 30 and $60 \mathrm{~d}$ after the injection of $25 \mu \mathrm{g}$ of pCMVtkluc (Fig. 2). However, this increase was significant only when results from 2 and $60 \mathrm{~d}$ were compared ( $t$-test, $p=0.02$ ). In all the experiments per-

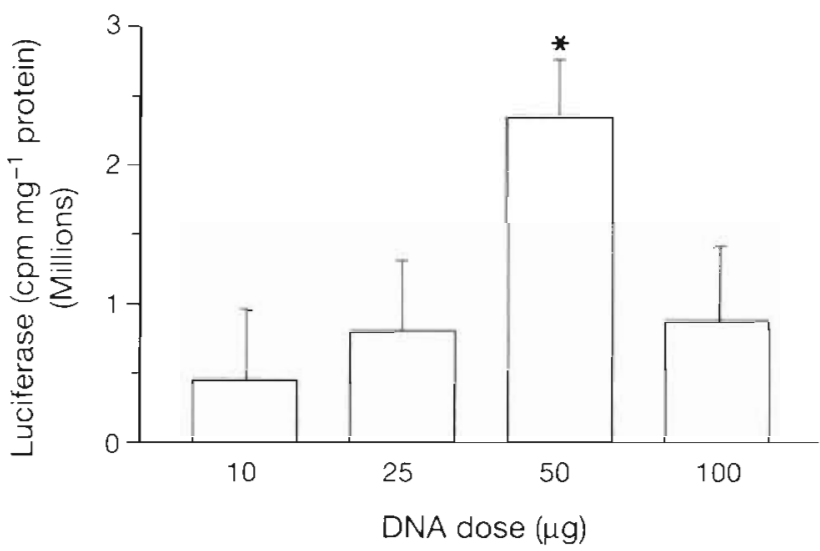

Fig. 1 Effect of DNA dose on luciferase expression after injection. Mean $( \pm \mathrm{SE})$ luciferase expression in muscle tissue lysates from trout sacrificed $2 \mathrm{~d}$ after injection of $10,25,50$. and $100 \mu \mathrm{g}$ of the plasmid pCMVtkluc. * Significant difference ( $t$-test, $p<0.05$ ) between the $50 \mu \mathrm{g}$ dose and the 10,25 , and $100 \mu \mathrm{g}$ doses

formed, $100 \%$ of the injected fish expressed the luciferase gene $(n=25)$, with levels ranging from $1.8 \times 10^{4}$ to $1.4 \times 10^{8} \mathrm{cpm} \mathrm{mg}^{-1}$ protein. In order to test other tissue targets, we injected $25 \mu \mathrm{g}$ of the plasmid pCMVtkluc into the gills and the peritoneum of trout. No luciferase expression was observed in tissue lysates from these fish when sacrificed $2 \mathrm{~d}$ after injection (data not shown).

Histological examination of tissue samples from trout injected intramuscularly with the plasmid pCMVtklacz showed some damage to the muscle tissue and the presence of inflammatory cells in the needle track, but no necrosis (Fig. 3). Immunohistochemical localization of $\beta$-galactosidase expression showed groups of muscle cells expressing the protein localized close to the needle track (Fig. 3). Endogenous $\beta$-galactosidase

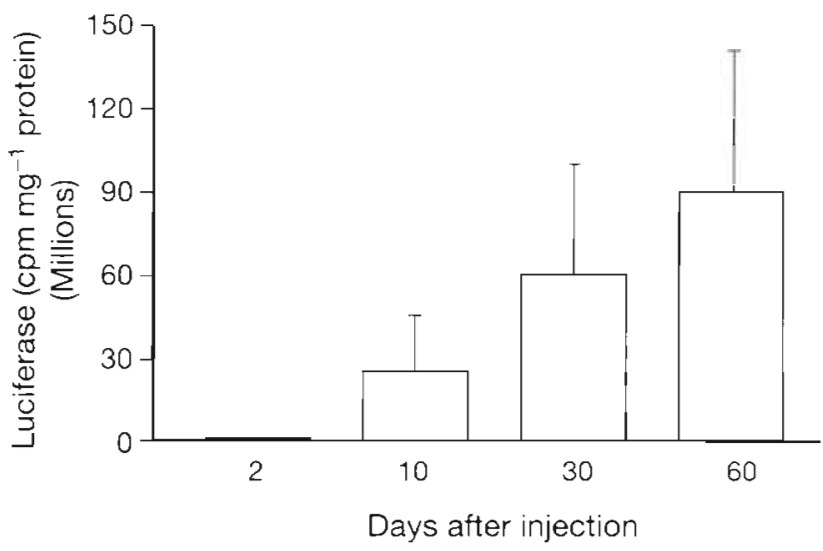

Fig. 2. Time course of luciferase expression after injection Mean ( \pm SE) luciferase expression in muscle tissue lysates from trout sampled at various time points after the injection of $25 \mu \mathrm{g}$ of the plasmid pCMVtkluc 


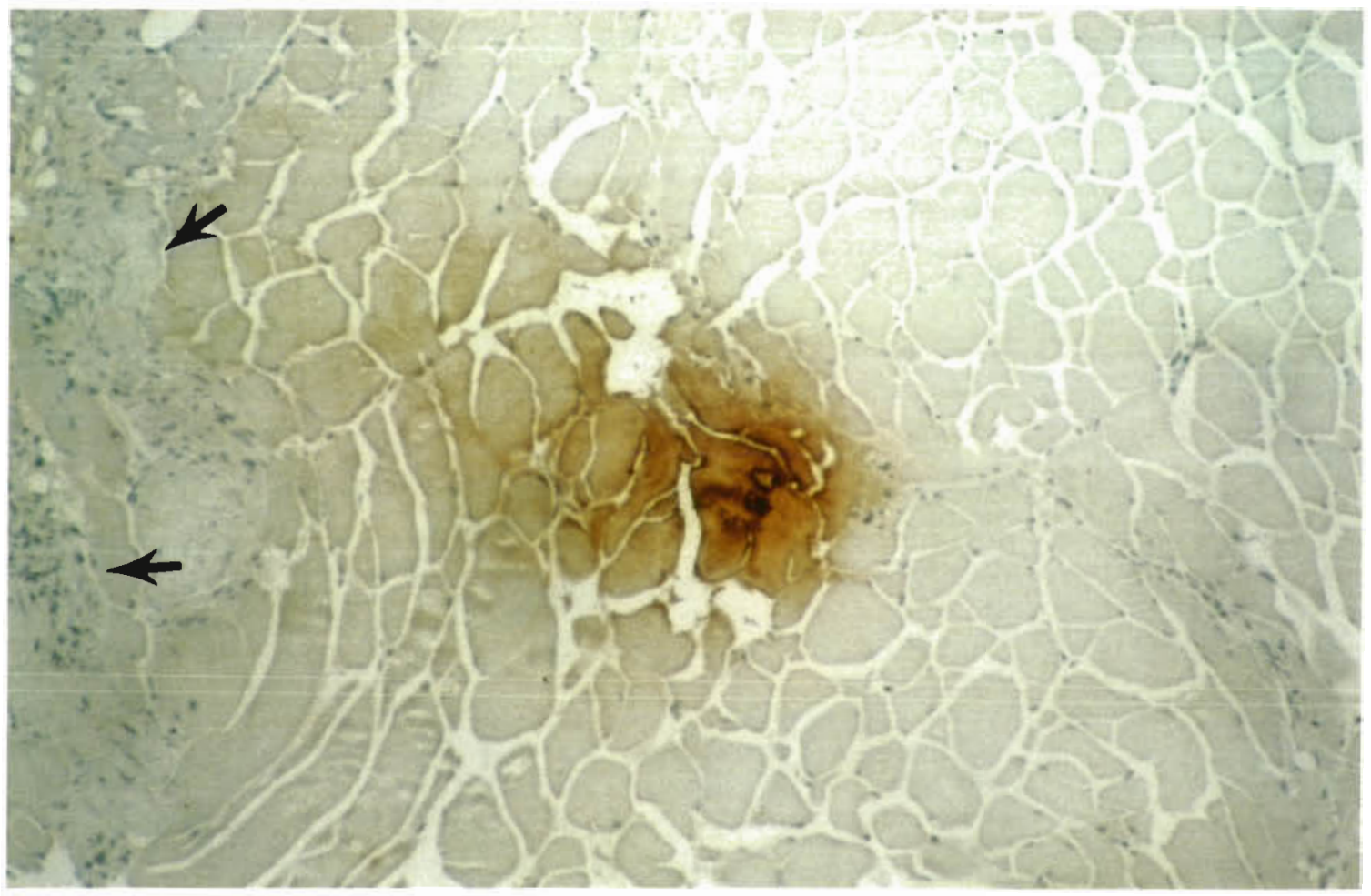

Fig. 3. Immunohistochemical localization of $\beta$-galactosidase expression after injection. Transverse cross-sections of muscle tissue were sampled from trout sacrificed $2 \mathrm{~d}$ after the injection of $25 \mu \mathrm{g}$ of $\mathrm{pCMVtklacz}$. Arrow indicates where the muscle tissue has been disrupted by the needle and infiltration of blood and inflammatory cells is observed. $\beta$-galactosidase expression in muscle cells is shown as a brown pigment. $(\times 40)$

Table 1. Effect on luciferase expression of the helium pressure used in particle bombardment. Trout were bombarded in the area between the dorsal fin and the lateral line at varying helium pressures with $750 \mu \mathrm{g}$ of $1 \mu \mathrm{m}$ gold particles coated with either 5 or $11 \mu \mathrm{g}$ (indicated by the asterisk) of pCMVtkluc

\begin{tabular}{|ccc|}
\hline $\begin{array}{c}\text { Helium pressure } \\
(\mathrm{kPa})\end{array}$ & $\begin{array}{c}\text { No. of positive fish/total } \\
\text { no. of fish }\end{array}$ & $\begin{array}{c}\text { Range of luciferase } \\
\text { expression (cpm } \mathrm{mg}^{-1} \text { protein) }\end{array}$ \\
\hline 2750 & $3 / 3$ & $286-579$ \\
4500 & $2 / 3$ & $95-490$ \\
6200 & $2 / 3$ & $90-542$ \\
7600 & $2 / 2$ and $3 / 3^{\circ}$ & $776-2992$ and $239-21582^{\circ}$ \\
7900 & $4 / 5^{\circ}$ & $128-2264^{\circ}$ \\
12400 & $0 / 3^{\circ}$ & 0 \\
\hline
\end{tabular}

Table 2. Effect on luciferase expression of the DNA dose used in particle bombardment. Trout were bombarded in the area between the dorsal fin and the lateral line at a helium pressure of $7600 \mathrm{kPa}$ with $750 \mu \mathrm{g}$ of $1 \mu \mathrm{m}$ gold particles coated with varying amounts of the plasmid pCMVtkluc

\begin{tabular}{|ccc|}
\hline $\begin{array}{c}\text { DNA dose } \\
\left(\mu \mathrm{gfish} \mathrm{fi}^{-1}\right)\end{array}$ & $\begin{array}{c}\text { No. of positive fish/total } \\
\text { no. of fish }\end{array}$ & $\begin{array}{c}\text { Range of luciferase } \\
\text { expression (cpm } \mathrm{mg}^{-1} \text { protein) }\end{array}$ \\
\hline 0.3 & $0 / 3$ & 0 \\
2 & $0 / 3$ & 0 \\
5 & $2 / 2$ & $776-2992$ \\
11 & $3 / 5$ & $239-21582$ \\
25 & $4 / 10$ & $208-496$ \\
\hline
\end{tabular}

activity was observed in intestine and kidney of control fish, but never in the dermis, epidermis, or muscle (data not shown).

The conditions for the delivery of DNA by particle bombardment were evaluated using gold particles coated with the plasmid pCMVtkluc, and the flank muscle as target. The different trials showed that it is necessary to use at least $600 \mu \mathrm{g}$ of gold particles per bombardment in order to achieve measurable levels of luciferase expression. The highest mean levels of luciferase expression $\left(1.2 \times 10^{4} \pm 0.9 \times 10^{4} \mathrm{cpm}\right.$ $\mathrm{mg}^{-1}$ protein, $\mathrm{n}=3$ ) were measured in tissue homogenates of skin and muscle from fish bombarded with $750 \mu \mathrm{g}$ of $1 \mu \mathrm{m}$ gold particles coated with $11 \mu \mathrm{g}$ of DNA at a helium pressure of $7600 \mathrm{kPa}$. Similar levels of luciferase expression were obtained with helium pressures in the 2750 to $12400 \mathrm{kPa}$ range (Table 1), DNA concentrations of 5 and $25 \mu \mathrm{g} \mathrm{fish}{ }^{-1}$ (Table 2), and 
particle sizes of $1,1.6$ and $2.2 \mu \mathrm{m}$ (Table 3). Overall, luciferase levels were highly variable (ranging from 64 to $2.1 \times 10^{4} \mathrm{cpm} \mathrm{mg}^{-1}$ protein). The levels of luciferase expression observed after in vivo transfection by particle bombardment were significantly lower $(l$-test, $p<0.02$ ) than the levels obtained after direct injection. Moreover, only $59 \%(n=27)$ of the bombarded fish showed increased levels of luciferase activity, while high levels of luciferase activity were observed in $100 \%(n=25)$ of the injected fish.

The striking differences observed in the efficiency of in vivo transfection between injection and particle bombardment may result in part from the natural barrier to particle penetration formed by the scales. Visual

Fig. 4. Effect of tissue target in luciferase expression after particle bombardment. Mean ( \pm SE) luciferase expression in the eye and different regions of the flank muscle. Trout were sacrificed $2 \mathrm{~d}$ after bombardment with $750 \mu \mathrm{g}$ of $1 \mu \mathrm{m}$ gold particles coated with $11 \mu \mathrm{g}$ of pCMVtkluc at 2 different helium pressures
Table 3. Effect on luciferase expression of the size of the particles used for the bombardments. Trout were bombarded in the area between the dorsal fin and the lateral line at a helium pressure of $7900 \mathrm{kPa}$ with $750 \mu \mathrm{g}$ of gold particles of various sizes coated with $11 \mu \mathrm{g}$ fish $^{-1}$ of pCMVtkluc

\begin{tabular}{|ccc|}
\hline $\begin{array}{c}\text { Particle size } \\
(\mu \mathrm{m})\end{array}$ & $\begin{array}{c}\text { No. of positive fish/total } \\
\text { no. of fish }\end{array}$ & $\begin{array}{c}\text { Range of luciferase } \\
\text { expression }\left(\mathrm{cpm} \mathrm{mg}^{-1} \text { protein) }\right.\end{array}$ \\
\hline 1.0 & $4 / 5$ & $128-2264$ \\
1.6 & $3 / 4$ & $64-1860$ \\
2.2 & $3 / 5$ & $170-616$ \\
\hline
\end{tabular}
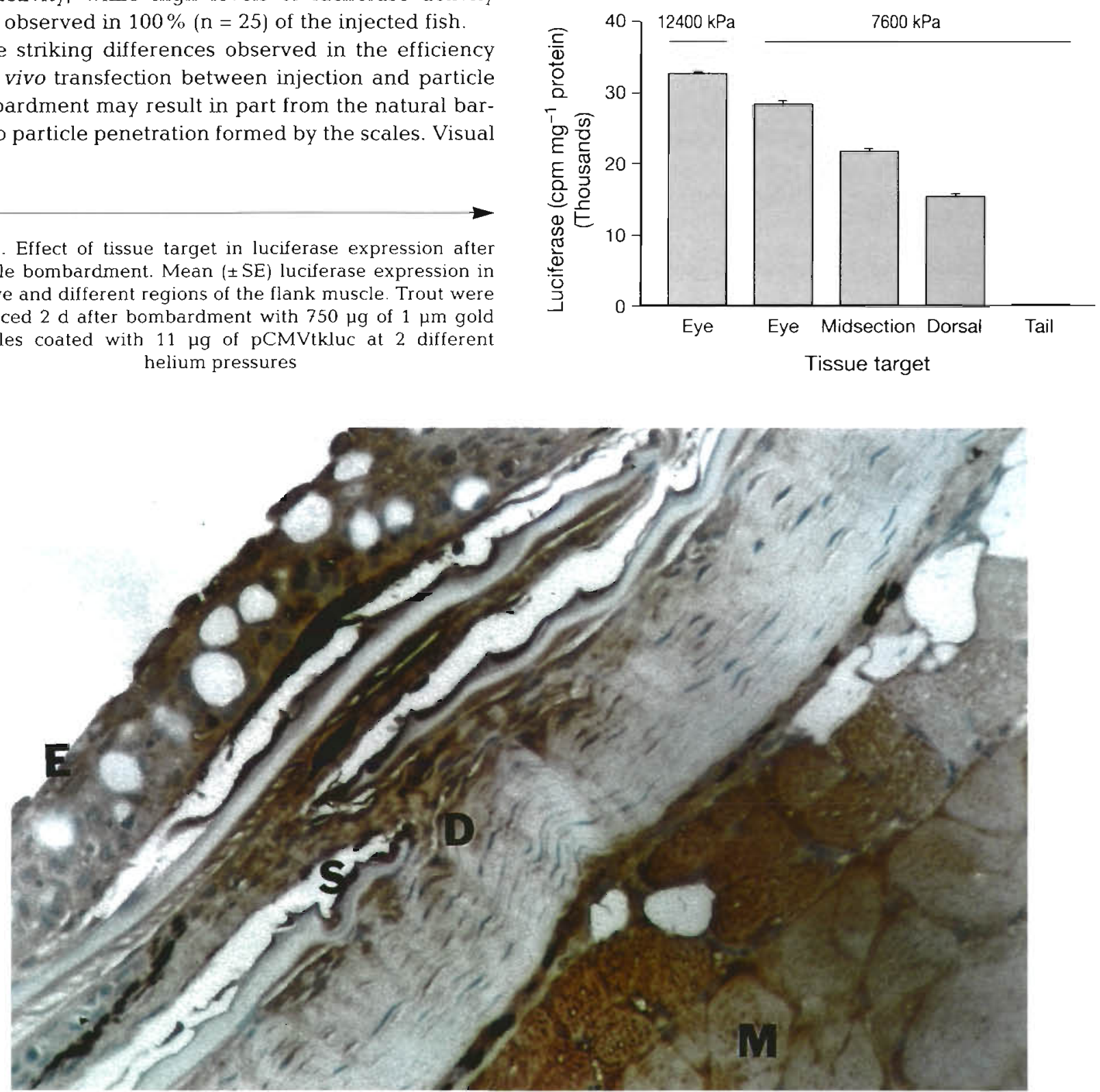

Fig. 5. Immunohistochemical localization of $\beta$-galactosidase expression after particle bombardment. Tissue sections were prepared from trout sacrificed $2 \mathrm{~d}$ after the bombardment. Trout were bombarded in the area between the dorsal fin and the lateral line at a helium pressure of $7600 \mathrm{kPa}$ with $750 \mu \mathrm{g}$ of $1 \mu \mathrm{m}$ gold particles coated with $11 \mu \mathrm{g}$ of pCMVtklacz. $\beta$-galactosidase expression is observed in the path of particle penetration in epidermal (E), dermal (D), and muscle cells (M). S: scales. $(\times 100)$ 
examination of the skin of the trout after bombardment revealed that most of the gold particles remained on the surface of the scales and were washed off afterwards. In order to test other tissue targets for particle bombardment, trout were bombarded in the following sites: eye, gills, midsection of the body, further down in the flank between the dorsal fin and the lateral line, and close to the tail (Fig. 4). Although still variable, the best results were obtained with the eye as target $183 \%$ of fish positive, $n=6$, versus $59 \%$ of fish positive when bombarded in the flank muscle). The levels of luciferase expression observed in the eye were not statistically different from the levels observed in the flank muscle. No luciferase expression was observed in the gills (data not shown)

Immunohistochemical analysis of samples from trout bombarded with the plasmid pCMVtklacz was performed in order to evaluate the type and location of the cclls expressing the reporter gene after particle bombardment. Trout bombarded in the flank with $1 \mu \mathrm{m}$ gold particles at helium pressures up to $12400 \mathrm{kPa}$ showed $\beta$-galactosidase expression in cells located in the epidermis and dermis of the bombarded area, as well as in a small percentage of muscle cells in the path of the particles (Fig. 5). This observation suggests that particle penetration may be slowed down, or even blocked, by the scales of the trout. However, a small percentage of cells located deeper in the muscle tissue also showed $\beta$-galactosidase expression, indicating that some particles penetrate deep beyond the dermis (data not shown).

\section{DISCUSSION}

We have determined here the optimal conditions for the physical delivery of DNA into the tissue of live trout by direct injection and particle bombardment. Techniques for the physical delivery of DNA have proven to be very attractive because a variety of vectors can be introduced into the tissue of live animals with ease and speed, involving little more than the construction of an appropriate expression plasmid. Both direct injection and particle bombardment have been previously used in genetic immunization studies for the delivery of plasmid vectors that contain genes coding for antigenic proteins (Tang et al. 1992, Cox et al. 1993, Fynan et al. 1993, Ulmer et al. 1993, Wang et al. 1993, Raz et al. 1994, Sedegah et al. 1994, Barry et al. 1995. Manickan et al. 1995). In direct injection, substantial quantities of DNA are introduced into the muscle tissue to achieve vector uptake and antigen expression (Benvenisty \& Reshef 1986, Wolff et al. 1990, 1992). Although injection is a simple and rapid method of gene delivery, most of the DNA does not reach. the target cells and may be degraded in the extracellular space. On the other hand, particle bombardment has been previously shown to result in the direct intracellular delivery of a DNA-coated microparticle into the target cell (Hansen et al. 1991, Eisenbraun et al 1993, Sanford 1993).

The results presented here indicate that these 2 gene transfer techniques are suitable methods of gene delivery into selected tissues of fish. We have observed prolonged levels of gene expression in the muscle of trout after injection of DNA and in the skin after particle bombardment of DNA-coated gold particles. The continued expression of the antigen by the trout cells may result in a longer-lasting immune response than that obtained by protein or recombinant vaccines.

We have observed here that injection is rapid, simple, reproducible, and results in significantly higher levels of gene expression than when using particle bombardment. On the other hand, the hand-held gene gun has the advantage that many tissues that can not be transfected in vivo by direct injection can be selectively accessed by the gold particles by adjusting the conditions of the bombardment. Moreover, the amount of DNA necessary to achieve gene expression is smaller in the case of particle bombardment. Similar results have been reported for rats and mice (Eisenbraun et al. 1993, Fynan et al. 1993, Raz et al. 1994)

The substantial differences in the levels of expres. sion that we observed after injection or particle bombardment may result from the fact that most of the bombarded microparticles remain on the scales and do not penetrate into the muscle tissue. Therefore, while reporter gene expression was mostly observed in muscle cells after injection, cells from the epidermis and dermis were the main target of the DNAcoated gold microprojectiles in particle bombardment. Previous experiments have demonstrated that muscle cells are unique among mammalian cells types in their capacity to take up and express free DNA (Wolff et al. 1990, Acsadi et al. 1991), and trout muscle cells seem to share this ability. However, the efficacy of different routes of genetic immunization not only depends on the efficiency of the transfection, but also on the efficiency with which transfected cells present proteins to the immune system. In this respect, the most efficient DNA-based immunization against the influenza virus in mice has been achieved by using particle bombardment of the epidermis (Fynan et al. 1993). This probably results from the fact that the skin, as one of the first sites that encounter most foreign antigens, contains all immunological components necessary for the induction of humoral and cellular immune responses. Therefore, the superior properties of the cells in the 
dermis and epidermis with regard to antigen presentation and recognition may compensate for the lower transfection efficiency. Finally, we have observed that the eye showed a higher reproducibility in plasmid uptake and expression after particle bombardment. However, it is known that in mammals the eye is an immunologically 'privileged' site in which the inflammatory response is suppressed (for review, see Streilein et al. 1992). The lack of an immune response in the eye against the expressed antigen of the fish could make this site a poor choice of target for DNAbased immunization.

In order to develop DNA-based vaccines for 2 serious bacterial diseases that affect salmonids, bacterial kidney disease and furunculosis, we have constructed expression vectors containing the CMV promoter coupled to the genes coding for p57, the $57 \mathrm{kD}$ extracellular protein from Renibacterium salmoninarum (Chien et al. 1992) and for a serine protease from Aeromonas salmonicida (Whitby et al. 1992). We are currently using both injection and particle bombardment to introduce these vectors into different tissues in the trout. We are studying the effects of the method of gene delivery and the site of transfection on the immune response against these expressed bacterial antigens. DNA-based immunization may prove to be very valuable for the design of safe and economic vaccines for bacterial diseases in fish.

\section{ADDENDUM}

While this paper was in press, we had access to a new prototype gene gun from BioRad, the Helios Gene Gun System. Similarly to the previous hand-held prototype, the Helios Gene Gun employs a high velocity stream of helıum to accelerate gold particles coated with DNA to velocities sufficient to penetrate cells in vivo. However, there are several umportant modifications to the system that makes it more user-friendly and efficient. We report here the results from experiments in which the transformation efficiency of both prototypes was compared.

Methods. Plasmid DNA was precipitated onto the gold particles following a modification of the $\mathrm{CaCl}_{2}$ protocol (Sanford 1993) and the manufacturer's instructions. The suspension of DNA-coated gold particles was coated onto the inner wall of Tefzel tubing using the Tubing Prep Unit (BioRad). The tubing was then cut into $1.3 \mathrm{~cm}$ length cartridges. Up to 12 cartridges were inserted into the cartridge holder of the Helium Gene Gun in order to perform repetitive particle bombardments. The helium discharge was initiated by pressing the trigger buttons which activated the main valve. The gold particles were pulled from the inside surface of the cartridge by the helium stream and were delivered to the tissue target.

Results and discussion. The results from the comparison between the 2 Gene Gun prototypes are shown in Tables 4 \& 5. Simılar levels of luciferase expression in skin and the first layers of muscle were obtained after bombardment with either of the 2 guns. However, the Helios Gene Gun System (new gun) seems to be more effective that the old gene gun, in the sense that lower pressures and significantly less DNA. are necessary to transform cells in $100 \%$ of the fish. We have observed that the new system is more user-friendly and reliable than the old one. The coating protocol provides up to 50 DNA-coated tubes in a single preparation, while the cartridge system and the hand-held gun design allow for the fast. transformation of any target accessible to the barrel
Table 4. Comparison between the 2 prototypes of Gene Gun (new and old). Effect on luciferase expression of the helium pressure used in particle bombardment. Trout were bombarded in the area between the dorsal fin and the lateral line at varying helium pressures with $750 \mu \mathrm{g}$ of $1 \mu \mathrm{m}$ gold particles coated with $5 \mu \mathrm{g}$ of pCMVtkluc and $5 \mu \mathrm{g}$ of pCMVtklacz

\begin{tabular}{|ccc|}
\hline $\begin{array}{c}\text { Helium pressure } \\
\text { (kPa) }\end{array}$ & $\begin{array}{c}\text { No. of positive fish/ } \\
\text { total no. of fish }\end{array}$ & $\begin{array}{c}\text { Range of luciferase } \\
\text { expression (cpm mg }{ }^{-1} \text { protein) }\end{array}$ \\
\hline 690 (new) & $3 / 3$ & $1348-4805$ \\
1375 (new) & $3 / 3$ & $567-7358$ \\
2050 (new) & $3 / 3$ & $3341-52527$ \\
2750 (new) & $2 / 3$ & $2360-5064$ \\
3450 (new) & $0 / 3$ & 0 \\
4125 (new) & $0 / 3$ & 0 \\
2750 (old) & $1 / 3$ & 947 \\
7600 (old) & 0.3 & 0 \\
\hline
\end{tabular}

Table 5. Comparison between the 2 prototypes of Gene Gun (new and old). Effect on luciferase expression of the DNA dose used in particle bombardment. Trout were bombarded in the area between the dorsal fin and the lateral line at a helium pressure of either 2050 (new gun) or 7600 (old gun) $\mathrm{kPa}$, with $750 \mu \mathrm{g}$ of $1 \mu \mathrm{m}$ gold particles coated with the plasmid pCMVtkluc

\begin{tabular}{|ccc|}
\hline $\begin{array}{r}\text { DNA dose } \\
\left(\mu \text { fish }^{-1}\right)\end{array}$ & $\begin{array}{c}\text { No. of positive fish/ } \\
\text { total no. of fish }\end{array}$ & $\begin{array}{c}\text { Range of luciferase } \\
\text { expression (cpm } \text { mg }^{-1} \text { protein) }\end{array}$ \\
\hline 0.10 (new) & $4 / 5$ & $1340-4150$ \\
0.25 (new) & $3 / 5$ & $1182-8828$ \\
0.50 (new) & $3 / 3$ & $1107-7312$ \\
1.00 (new) & $3 / 3$ & $2255-9126$ \\
2.50 (new) & $2 / 2$ & $126-1927$ \\
0.50 (old) & $1 / 3$ & 2046 \\
2.50 (old) & $2 / 3$ & $1952-4141$ \\
\end{tabular}


Acknowledgements. This work was supported by USDA CALR-9382971 and the American Cancer Society grant \# IRG-202. M. Gómez-Chiarri is a fellow of the Ministerio de Educación y Ciencia (Spain). We thank Dr Schartl at the Max Planck Institute in Martinsried, Germany, for providing the plasmids. We also thank our colleagues at Dr Alberte's laboratory and Drs L. Brown, P. Schulte, and S. Johnson, of Hopkins Marine Station, for their technical support and helpful suggestions in the preparation of the manuscript

\section{LITERATURE CITED}

Acsadi G, Jiao S, Jani A, Duke D, Williams P, Chang W, Wolff JA (1991) Direct gene transfer and expression into rat heart in vivo. New Biol 3:71-81

Barry MA, Lai CL, Johnston SA (1995) Protection against mycoplasma infection using expression-library immunization. Science 377:632-635

Benvenisty N, Reshef L (1986) Direct introduction of genes into rats and expression of the genes. Proc Natl Acad Sci USA 83:9551-9555

Chien MS, Gilbert T, Huang C, Landolt ML, O'Hara PJ, Winton RJ (1992) Molecular cloning and sequence analysis of the gene coding for the 57-kDa major soluble antigen of the salmonid fish pathogen Renibacterium salmoninarum. FEMS Microbiol Lett 96:259-266

Cox GJ, Zamb TJ, Babiuk LA (1993) Bovine herpesvirus 1: immune responses in mice and cattle injected with plasmid DNA. J Virol 67:5664-5667

Davis HL, Whalen RG (1995) DNA-based immunization. In: Dickson G (ed) Molecular and cell biology of human genetic therapeutics. Chapman and Hall, London, p 368-387

Eisenbraun MD, Fuller DH, Haynes JR (1993) Examination of parameters affecting the elicitation of humoral immune responses by particle bombardment-mediated genetic immunization. DNA Cell Biol 12:791-797

Fynan EF, Webster RG, Fuller DH, Haynes JR, Santoro JC, Robinson HL (1993) DNA vaccines: protective immunizations by parenteral, mucosal, and gene-gun inoculations. Proc Natl Acad Sci USA 90:11478-11482

Hansen E, Fernandes K, Goldspink G, Butterworth P, Umeda PK, Chang KC (1991) Strong expression of foreign genes following direct injection into fish muscle. FEBS Lett 290 : $73-76$

Leong JAC (1993) Molecular and biotechnological approaches to fish vaccines. Curr Opin Biotechnol 4: 286-293

Manickan E, Rouse RJD, Yu Z, Wire WS, Rouse BT (1995) Genetic immunization against herpes simplex virus: protection is mediated by $\mathrm{CD} 4+\mathrm{T}$ lymphocytes. J Immunol $155: 259-265$

Munn CB (1994) The use of recombinant DNA technology in the development of fish vaccines. Fish Shellfish Immunol $4: 459-473$

Newman SG (1993) Bacterial vaccines for fish. Annu Rev Fish Dis 3:145-185

Responsible Subject Editor: L. Vaughan, Dublin, Ireland
Press CM, Lillehaug A (1995) Vaccination in European salmonid aquaculture: a review of practices and prospects. Br Vet J 151:45-69

Raz E, Carson DA, Parker SE, Parr TB, Abai AM, Aichinger G, Gromkowski SH, Singh M, Lew D, Yankauckas MA, Baird SM, Rhodes GM (1994) Intradermal gene immunization: the possible role of DNA uptake in the induction of cellular immunity to viruses. Proc Natl Acad Sci USA 91: 9519-9523

Robinson HL, Hunt LA, Webster RG (1993) Protection against a lethal influenza virus challenge by immunization with a haemagglutinin-expressing plasmid DNA. Vaccine 11: $957-960$

Sanford JC (1993) Optimizing the biolistic process for different biological applications. In: Wu R (ed) Methods in enzymology, Vol 217, Recombinant DNA, Part H. Academic Press, Inc, San Diego, p 483-509

Sedegah M. Hedstrom R, Hobart P, Hoffman SL (1994) Protection against malaria by immunization with plasmid DNA encoding circumsporozoite protein. Proc Natl Acad Sci USA 91:9866-9870

Streilein JW, Wilbanks GA, Cousins SW (1992) Immunoregulatory mechanisms of the eye. J Neuroimmunol 39: $185-200$

Tang DC, De Vit M, Johnston SA (1992) Genetic immunization is a simple method for eliciting an immune response. Nature 356:152-154

Ulmer JB, Donelly JJ, Parker SE, Rhodes GH, Feigner PL, Dwarki VJ, Gromkowski SH, Deck RR, DeWitt CM, Friedman A, Hawe LA, Leander KR, Martinez D, Perry HC, Shiver JW, Montgomery DL, Liu MA (1993) Heterologous protection against influenza by injection of DNA encoding a viral protein. Science 259:1745-1749

Wang $B$, Ugen KE, Srikantan $V$, Agadjanyan $M G$, Damg $K$, Refaeli Y, Sato AI, Boyer J, Williams WV, Weiner DB (1993) Gene inoculation generates immune responses against human immunodeficiency virus type 1. Proc Natl Acad Sci USA 90:4156-4160

Whitby PW, Landon M, Coleman G (1992) The cloning and nucleotide sequence of the serine protease gene (aspA) of Aeromonas salmonicida ssp. salmonicida. FEMS Microbiol Lett 99:65-72

Williams RS, Johnston SA, Riedy M, DeVit MJ, McElligott SG, Sanford JC (1991) Introduction of foreign genes into tissues of live mice by DNA-coated microprojectiles. Proc Natl Acad Sci USA 88:2726-2730

Winkler C, Hong Y, Wittbrodt J, Schartl M (1992) Analysis of heterologous and homologous promoters and enhancers in vitro and in vivo by gene transfer into Japanese Medaka (Oryzias latipes) and Xiphophorus. Mol Mar Biol Biotechnol 1:326-337

Wolff JA, Ludtke JJ, Acsadi G, Williams P, Jani A (1992) Long-term persistence of plasmid DNA and foreign gene expression in mouse muscle. Human Mol Genetics 1 363-369

Wolff JA, Malone RW, Williams P, Chong W, Acscadi G, Jani A, Felgner PL (1990) Direct gene transfer into mouse muscle in vivo. Science 1990 247:1465-1468

Manuscript first received: February 26, 1996

Revised version accepted: April 29, 1996 